\title{
Analisis Sektor Unggulan Dalam Pengembangan Wilayah Kabupaten Kepulauan Meranti
}

\author{
Muhammad Hidayat ${ }^{1^{*}}$, Ranti Darwin ${ }^{2}$ \\ ${ }^{1,2}$ Faculty of Economics \& Business, Muhammadiyah University of Riau, Indonesia
}

\section{Informasi Artikel \\ Sejarah artikel: \\ Diterima Agustus 2017 \\ Disetujui September 2017 \\ Dipublikasikan Oktober 2017}

\section{Keywords:}

Location Quotient,

Shift Share Analysis,

Specialization Index

Regional Development

\begin{abstract}
A B S T R A C T
Meranti Islands Regency is one of the areas that are expected to be the gate of trade in the western of Indonesia. The strategic position lies between the two corridors of the Masterplan for Acceleration and Expansion of Indonesian Economic Development (MP3EI), namely the Pekanbaru corridor and the Batam corridor.Seeing these opportunities are expected to accelerate regional development. This study haveaims to identify and analyze potential sectors of the economy and formulate future development policies. The analytical tools are Location Quotient (LQ), Shift Share Analysis (SSA), and Specialization Index. This study used time series data in during2010-2015. The analysis results indicate that potential sectors based on the combined analysis of Location Quationt, Shift Share Analysis, and Specialization Index are Transportation and Warehousing Sector; Agricultural, Forestry and Fishery Sectors; and Processing Industry Sector. The sectors that are specialized in inter-regional interactions are Agriculture, Forestry and Fishery Sectors; And Transportation and Warehousing Sector.
\end{abstract}




\section{Pendahuluan}

Kebijakan pembangunan wilayah pada dasarnya merupakan keputusan dan intervensi pemerintah, baik secara nasional maupun regional untuk mendorong proses pembangunan daerah secara keseluruhan. Analisis ini sangat penting guna mempercepat pertumbuhan ekonomi daerah, meningkatkan penyediaan lapangan kerja dan penanggulangan kemiskinan pada wilayah-wilayah terbelakang. Semua ini diperlukan untuk dapat meningkatkan proses pembangunan wilayah dan sekaligus untuk meningkatkan kesejahteraan masyarakat setempat.

Pemerintah Indonesia mengeluarkan Undang-Undang No. 22 Tahun 1999tentang Pemerintah Daerah. Dalam undang-undang ini, otonomi daerah diusahakan untuk terwujud melalui pemberian wewenang yang lebih besar kepada daerah terutama kabupaten dan kota. Sedangkan kewenangan Pemerintah Pusat dibatasi hanya pada 5 (lima) sektor saja yaitu: pertahanan dan keamanan, politik luar negeri, fiskal dan moneter, peradilan dan agama. Sedangkan provinsi diberikan otonomi terbatas dalam pengelolaan pembangunan daerah selain yang diberikan kepada Pemerintah Pusat dan Provinsi akan menjadi kewenangan Pemerintah Daerah Kabupaten dan Kota. Peraturan Pemerintah (PP) No.25 tahun 2000 merinci secara tegas dan konkrit pembagian kewenangan tersebut.

Dalam upaya mencapai tujuan pembangunan ekonomi daerah, kebijakan utama yang perlu dilakukan adalah mengusahakan semaksimal mungkin agar prioritas pembangunan daerah sesuai dengan potensi yang dimiliki oleh daerah.Hal ini terkait dengan potensi pembangunan yang dimiliki setiap daerah sangat bervariasi,maka setiap daerah harus menentukan sektor ekonomi yang dominan (Sjafrizal 2014).

Tabel 1.

Persentase Kontribusi Sektoral terhadap PDRB Kabupaten Kepulaun Meranti Periode 2010-2014

\begin{tabular}{|c|c|c|c|c|c|c|}
\hline \multirow{2}{*}{ No } & \multirow{2}{*}{ Lapangan Usaha } & \multicolumn{5}{|c|}{ Tahun } \\
\hline & & 2010 & 2011 & 2012 & 2013 & 2014 \\
\hline 1 & Pertanian, Kehutanan,Perikanan & 40,57 & 32,39 & 30,57 & 32,62 & 32,07 \\
\hline 2 & Pertambangan dan Penggalian & 22,47 & 32,09 & 34,78 & 32,61 & 28,09 \\
\hline 3 & Industri Pengolahan & 23,06 & 22,21 & 20,73 & 20,07 & 18,30 \\
\hline 4 & Pengadaan Listrik dan Gas & 0,04 & 0,03 & 0,02 & 0,02 & 0,04 \\
\hline 5 & $\begin{array}{l}\text { Pengadaan Air, Pengelolaan Sampah, } \\
\text { Limbah dan Daur Ulang }\end{array}$ & 0,00 & 0,00 & 0,00 & 0,00 & 0,00 \\
\hline 6 & Konstruksi & 2,79 & 2,86 & 2,70 & 3,30 & 3,80 \\
\hline 7 & $\begin{array}{l}\text { Perdagangan Besar dan Eceran; Reparasi } \\
\text { Mobil dan Sepeda Motor }\end{array}$ & 5,66 & 5,46 & 6,08 & 5,62 & 11,84 \\
\hline 8 & Transportasi dan Pergudangan & 1,69 & 1,62 & 1,79 & 1,85 & 1,92 \\
\hline 9 & Penyediaan Akomodasi dan Makan Minum & 0,17 & 0,17 & 0,17 & 0,22 & 0,27 \\
\hline 10 & Informasi dan Komunikasi & 0,63 & 0,28 & 0,35 & 0,67 & 0,72 \\
\hline 11 & Jasa Keuangan dan Asuransi & 0,28 & 0,27 & 0,31 & 0,31 & 0,31 \\
\hline 12 & Real Estat & 0,31 & 0,33 & 0,34 & 0,35 & 0,37 \\
\hline 13 & Jasa Perusahaan & 0,00 & 0,00 & 0,00 & 0,00 & 0,00 \\
\hline 14 & $\begin{array}{l}\text { Administrasi Pemerintahan, Pertahanan dan } \\
\text { Jaminan Sosial Wajib }\end{array}$ & 1,86 & 1,81 & 1,74 & 1,87 & 1,75 \\
\hline 15 & Jasa Pendidikan & 0,20 & 0,19 & 0,17 & 0,21 & 0.21 \\
\hline 16 & Jasa Kesehatan dan Kegiata Sosial & 0,05 & 0,05 & 0,05 & 0,05 & 0,06 \\
\hline 17 & Jasa Lainnya & 0,21 & 0.23 & 0,21 & 0,22 & 0.24 \\
\hline
\end{tabular}
Sumber. PDRB Kabupaten Kep Meranti Menurut Lapangan Usaha 2010-2014, BPS Kab. Kep. Meranti 
Kabupaten Kep Meranti merupakan salah satu wilayah yang diharapkan bisa menjadi gerbang perdagangan Indonesia bagian barat selain itu posisi yang strategis yang terletak di antara dua koridor pusat ekonomi yang direncanakan dalam dokumen Masterplan Percepatan dan Perluasan Pembangunan Ekonomi Indonesia (MP3El) yakni koridor Pekanbaru dan koridor Batam. Melihat peluang yang ada, diharapakan untuk mempercepat pembangunan daerah dengan mengelola dan memanfaatkan kekayaan serta potensi yang dimiliki, maka perhatian utama ditujukan dengan melihat komposisi ekonomi dengan mengetahui sumbangan atau peranan masing-masing kegiatan ekonomi.

Berdasarkan Tabel 1 Persentase kontribusi sektoral terhadap PDRB Kabupaten Kepulauan Meranti periode 20102014 mengalami fluktuasi dan selama lima tahun terakhir sektor pertanian memiliki kontribusi cukup besar jika dibandingkan dengan sektor lain. Pada tahun 2010 dapat dilihat kontribusi sektor pertanian, kehutanan dan perikanan menduduki peringkat tertinggi yaitu sebesar 40,57 persen. Selanjutnya sektor pertambangan dan penggalian menduduki urutan kedua yang memberikan kontribusi terbesar sekitar 22,47 persen pada tahun 2010, kemudian diikuti oleh sektor industri pengolahan 23,06 persen. Berikutnya disusul oleh sektor perdagangan besar dan eceran, reparasi mobil dan sepeda motor dengan kontribusi masing-masing sekitar 5,66 persen.

Pada tahun 2014 diketahui bahwa sektor pertanian, kehutanan dan perikanan memiliki peringkat tertinggi dengan kontribusi sebesar 32,07 persen dan diikuti oleh sektor pertambangan dan penggalian sebesar 28,09 persen dan disusul oleh sektor industri pengolahan sebesar 18,30 persen. Pada tahun 2014 kontribusi sektor perdagangan besar dan eceran, reparasi mobil dan sepeda motor mengalami kenaikan yang signifikan dibandingkan tahun- tahun sebelumnya yaitu sebesar 11,84 persen.

Tingginya kontribusi sektor pertanian, kehutanan dan perikanan, pertambangan dan penggalian, industri pengolahan dan sektor perdagangan besar dan eceran, reparasi mobil dan sepeda motor memberikan gambaran bahwa sektor tersebut memberikan kontribusi besar terhadap pertumbuhan ekonomi di Kabupaten Kep Meranti sebagai ciri dari suatu daerah yang mulai berkembang. Namun demikian, meskipun pertumbuhan ekonomi Kabupaten Kepulauan Meranti ini berkembang secara pesat, disisi lain Kabupaten Kep Meranti masih tergolong kedalam kategori daerah yang masih tertinggal. Hal ini mendorong perlunya sebuah perencanaan yang matang dalam pengembangan wilayah secara berkelanjutan sehngga Kabupaten Kep Meranti dapat meninggalkan posisi daerah tertinggal.

Penelitian Rudi et al. (2014) dengan menggunakan metode tipologi klassen, Location Quotient (LQ), Shift Share Analysis (SSA), dan Indeks Gravity dengan periode 2006-2012. Hasil LQ menunjukkan bahwa sektor pertambangan dan penggalian merupakan sektor unggulan Siak, Bengkalis, dan Rokan Hilir. Sektor pertanian menjadi unggulan di Kuantan Singingi, Indragiri Hulu, Indragiri Hilir, Pelalawan, Rokan Hulu dan Kampar. Sektor industri pengolahan menjadi sektor unggulan di Dumai. Sektor jasa menjadi unggulan di Pekanbaru. Hasil SSA menunjukkan adanya pergeseran potensi pertumbuhan ekonomi di Riau.

Penelitian yang dilakukan oleh Putra \& Kartika (2013) alat analisis yang digunakan Location Quotien (LQ), Model Rasio Pertumbuhan (MRP), dan analisis overlay. Hasil penelitian menyatakan bahwa sektor dominan di Kabupaten Badung adalah sektor listrik, gas, dan air bersih, sektor bangunan, sektor perdagangan, hotel, dan restoran, dan sektor pengangkutan dan komunikasi. 
Penelitian Deddy \& Irwansyah (2013) menggunakan alat analisis Location Quotient (LQ), Classical Shift Share dan Esteban Marquillas' Shift Share. Berdasarkan kombansi analisis ditemukan bahwa sektor ekonomi potensial yang memiliki daya saing yang tinggi, memiliki keunggulan kompetitif, mampu spesialis, serta memiliki keunggulan komparatif di masing-masing wilayah pengembangan Kabupaten Bekasi adalah sebagai berikut: untuk sektor pertanian dan transportasi, pembangunan wilayah I, II dan IV memiliki potensi; sektor pertambangan hanya potensial di wilayah I; Sektor Industri hanya potensial di wilayah II; Sektor konstruksi hanya bisa ditemukan dipengembangan wilayah II dan IV, untuk sektor perdagangan wilayah IV terbukti potensial; Sektor keuangan hanya potensial pada pengembangan wilayah II.

Penelitian Syarifah (2012) alat analisis yang digunakan Tipologi Klassen, Location Qoutient (LQ), Indeks Spesialisasi Regional. Hasil penelitian menyatakan daerah yang memiliki sektor unggulan terbanyak adalah Kabupaten Banyumas dengan tujuh sektor unggulan. Secara keseluruhan dapat dilihat bahwa sektor unggulan di Jawa Tengah yaitu sektor pertanian; keuangan, persewaan dan jasa perusahaan, dan sektor jasa-jasa. Berdasarkan indeks spesialisasi regional, hanya kota Magelang yang terspesialisasi terutama pada sektor tersier.

Penelitian Rosyetti (2011) metode yang digunakan adalah metode Location Quotient (LQ) dan Shift Share Analysis. Dari hasil pengamatan, diperoleh temuan: (a) sektor potensial yang berpotensi dalam meningkatkan perekonomian dan penyerapan tenaga kerja adalah sektor pertanian. Sektor jasa kurang berpotensi dalam peningkatkan perekonomian daerah dan penyerapan tenaga kerja, (b) Perubahan struktur ekonomi terjadi pada sektor pertambangan. Faktor spatial atau lokasional yang menguntungkan menyebab- kan berpotensinya sektor pertambangan dalam meningkatkan kesempatan kerja wilayah.

Penelitian Kornita (2008) dalam menentukan sektor unggulan dengan pendekatan LQ periode 2002-2006. Hasil menunjukkan bahwa sektor unggulan di Pekanbaru adalah sektor perdagangan dan jasa. Aktivitas ekonomi di Kampar di dorong sektor pertambangan dan penggalian. Perekonomian Bengkalis menunjukkan bahwa aktivitas perdagangan dan jasa memiliki keunggulan. Rokan hilir memiliki sektor unggulan pada sektor pertanian sub sektor perkebunan. Sektor unggulan Indragiri Hilir adalah sektor pertanian. Pengembangan Indragiri Hulu adalah sektor pertanian dan industri pengolahan. Kuantan singingi, sektor pertanian unggul untuk dikembangkan. Sektor industri pengolahan masih menjadi sektor unggulan di Pelalawan. Aktivitas ekonomi Siak didorong dengan keberadaan industri pengolahan. Potensi yang ada di Dumai menunjukkan sektor unggulan adalah sektor perdagangan dan jasa(Kornita 2008).

Berdasarkan latar belakang yang telah diuraikan diatas, maka yang menjadi pokok permasalahan dalam penulisan ini adalah mengidentifikasi dan menganalisis sektor potensial serta merumuskan kebijakan pengembangan wilayah Kabupaten Kep Meranti kedepan.

\section{Metode Penelitian}

Penelitian ini merupakan penelitian kuantitatif dengan menggunakan metode deskriptif. Alur penelitian meliputi pengumpulan data, tahap analisis sektor potensial, dan forecasting perekonomian kedepan. Penelitian ini menggunakan data sekunder runtun waktu (time series) periode tahun 2011-2015, yang diperoleh dari berbagai laporan dan kompilasi data serta bentuk publikasi lainnya, seperti dari Badan Pusat Statistik dan Badan Perencana Pembangunan Daerah Kabupaten Kep Meranti. 


\section{Location Quotient (LQ)}

Metode ini digunakan untuk menjawab rumusan masalah dan tujuan penelitian tentang sektor basis dan non basis, serta penentuan komoditi unggulan. Metode LQ merupakan salah satu pendekatan yang umum digunakan dalam model ekonomi basis sebagai langkah awal untuk memahami sektor kegiatan dari PDRB Kabupaten Kep Meranti yang menjadi pemicu pertumbuhan.

Perhitungan nilai LQ menggunakan metode yang mengacu pada formula sebagai berikut: (Sjafrizal 2012)

$$
\mathrm{LQ}=\frac{\frac{P D R B_{m i}}{\sum P D R B_{m}}}{\frac{P D R B_{s b i} i}{\sum P D R B_{s b}}}
$$

Dimana: $P D R B_{m i}=P D R B$ sektor $\mathrm{i}$ di Kabupaten Kep Meranti pada tahun tertentu. $\sum$ PDRB $_{m}=$ Total PDRB di Kabupaten Kep Meranti pada tahun tertentu. PDRB ${ }_{s b, i}=$ PDRB sektor i di Propinsi Riau pada tahun tertentu. $\sum$ PDRB $_{s b}=$ Total PDRB di Propinsi Riau pada tahun tertentu.

Apabila nilai $L Q>1$, maka dapat disimpulkan bahwa sektor tersebut merupakan sektor basis dan potensial untuk dikembangkan sebagai penggerak perekonomian Kabupaten Kep Meranti. Sebaliknya apabila nilai $L Q<1$, maka sektor tersebut bukan merupakan sektor basis dan kurang potensial untuk dikembangkan sebagai penggerak perekonomian Kabupaten Kep Meranti.

\section{Analisis Shift Share}

Melalui analisis shift share, maka pertumbuhan ekonomi dan pergeseran struktural perekonomian wilayah Kabupaten Kep Meranti ditentukan oleh tiga komponen, yaitu: (1) Provincial Share (PS), Hasil perhitungan Provincial Share akan menggambarkan peranan wilayah Propinsi Riau yang mempengaruhi pertumbuhan perekonomian Kabupaten Kep
Meranti. Jika pertumbuhan Kabupaten Kep Merantisama dengan pertumbuhan Propinsi Riau maka peranannya terhadap propinsi tetap, (2) Proportional Shift (P) digunakan untuk mengukur perubahan relatif, pertumbuhan atau penurunan, pada daerah dibandingkan dengan perekonomian yang lebih besar yang dijadikan acuan. Pengukuran ini untuk mengetahui apakah perekonomian daerah terkonsentrasi pada industri-industri yang tumbuh lebih cepat ketimbang perekonomian yang dijadikan acuan, (3) Differential Shift (D) digunakan untuk membantu dalam menentukan seberapa jauh daya saing industri daerah (lokal) dengan perekonomian yang dijadikan acuan. Oleh karena, itu jika pergeseran diferensial dari satu industri adalah positif, maka industri tersebut lebih tinggi daya saingnya dibanding industri yang sama pada perekonomian yang dijadikan acuan.

Secara matematis, Provincial Share (PS), Proportional Shift (P), dan Differential Shift (D) dapat diformulasikan sebagai berikut (Sjafrizal 2012):

$$
\Delta y_{i}=P S+P S+D S
$$

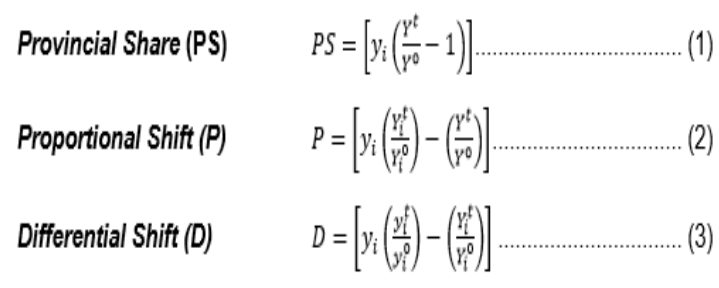

Dimana: $\Delta \mathrm{y}_{i}=$ Perubahan nilai tambah sektor $\mathrm{i} ; \mathrm{y}_{i}^{0}=$ nilai tambah sektor $\mathrm{i}$ di daerah pada awal periode; $\mathrm{y}_{i}^{\mathrm{t}=}$ nilai tambah sektor i di daerah pada akhir periode; $\mathrm{Y}_{i}^{0}=$ nilai tambah sektor i di tingkat nasional pada awal periode; $Y_{i}^{t}=$ nilai tambah sektor i di tingkat nasional pada akhir periode.

Perubahan nilai tambah bruto sektor tertentu (i) dalam PDRB Kabupaten Kep Meranti merupakan penjumlahan Provnicial Share (PS), Proportional Shift $(P)$, dan Differential Shift (D) sebagai berikut: Kedua komponen shift, yaitu Propor- 
tional Shift $(P)$ dan Differential Shift (D) memisahkan unsur-unsur pertumbuhan regional yang bersifat eksternal dan internal. Proportional Shift (P) merupakan akibat pengaruh unsur-unsur eksternal yang bekerja secara nasional (Propinsi), sedangkan Differential Shift (D) adalah akibat dari pengaruh faktor-faktor yang bekerja di dalam daerah yang bersangkutan (Sjafrizal 2014).

Sektor-sektor di Kabupaten Kep Meranti yang memiliki Differential Shift (D) positif memiliki keunggulan komparatif terhadap sektor yang sama pada Kabupaten/ Kota lain dalam Propinsi Riau. Selain itu, sektor-sektor yang memiliki nilai $D$ positif berarti bahwa sektor tersebut terkonsentrasi, memiliki daya saing yang tinggi dan mempunyai pertumbuhan yang lebih cepat dibandingkan dengan daerah lainnya. Apabila nilai $D$ negatif, maka tingkat pertumbuhan sektor tersebut relatif lamban.

\section{Analisis Pergeseran Bersih Shift Share}

Hasil analisis ini akan terlihat pergeseran cepat atau lambat dengan cara menjumlahkan hasil $\mathrm{P}$ dan $\mathrm{D}$, maka akan diperoleh pergeseran bersih yang dapat digunakan untuk mengidentifikasi pertumbuhan sektor perekonomian. Pergeseran bersih sektor i pada wilayah tertentu dapat dirumuskan sebagai berikut:

$$
P B_{i j}=P_{i j}+D_{i j}
$$

Apabila $\mathrm{PBij}>0$, maka pertumbuhan sektor i pada wilayah j termasuk ke dalam kelompok progresif (maju) PBij <0, maka pertumbuhan sektor i pada wilayah j termasuk lamban.

\section{Indeks Spesialisasi}

Indeks Spesialisasi (IS) merupakan teknik analisis yang dapat melengkapi dan/atau memperkuat hasil analisis LQ. Teknik analisis IS menunjukkan apakah suatu wilayah cenderung memiliki aktivitas yang terdiversifikasi atau cenderung me- miliki aktivitas yang tidak terspesialisasi. Apabila suatu wilayah memiliki aktivitas yang terdiversifikasi berarti wilayah tersebut tidak memiliki aktivitas basis tertentu, sebaliknya jika suatu wilayah memiliki aktivitas yang terspesialisasi berarti wilayah tersebut cenderung memiliki aktivitas basis tertentu (Hidayat 2014).

Metode perhitungan indeks spesialisasi regional yang lain sebagaimana yang diterapkan oleh Kim (Kim 1995)

$$
S I_{j k}=\sum_{i=1}^{n}\left|\frac{E_{y}}{E_{j}}-\frac{E_{i k}}{E_{k}}\right|
$$

Keterangan:SI $\mathrm{I}_{j k}=$ Indeks Spesialisasi Kabupaten/ Kota $\mathrm{j}$ dan k; $\mathrm{E}_{i j}=$ PDRB sektor i pada Kabupaten/kota j; $E=$ Total PDRB Kabupaten / kota j; $E_{i k}=$ PDRB sektor $i$ pada Kabupaten / kota k; $\mathrm{E}_{k}=$ Total PDRB Kabupaten k

Kriteria pengukuran menurut Kim: a) Bila Indeks Spesialisasi regional mendekati nol maka kedua daerah j dan $\mathrm{k}$ tidak memiliki spesialisasi, dan bila angka indeks mendekati dua maka kedua daerah j dan k memiliki spesialisasi; b) Batas tengah antara angka nol dan dua tersebut adalah satu, oleh karena itu nilai indeks spseialisasi yang lebih besar dari satu dapat diangaap sebagai sektor/ subsektor yang memiliki spesialisasi; c) Untuk melihat tinggi rendahnya tingkat spesialisasi suatu daerah terhadap daerah lainnya, sebagai pembanding digunakan nilai ratarata indeks spesialisasi seluruh daerah.

\section{Hasil dan Pembahasan \\ Struktur Ekonomi dan Pertumbuhan Ekonomi Kabupaten Kep Meranti}

Struktur perekonomian masyarakat di Kep Meranti didominasi oleh tiga kategori besar yaitu kategori pertanian, kehutanan dan perikanan (43,89 persen); kategori industri pengolahan (33,81 persen); dan kategori perdagangan besar dan eceran (9,17 persen). Hal ini terlihat dari besarnya peranan masing-masing kategori ini ter- 
hadap pembentukan PDRB Kabupaten Kep Meranti jika dibandingkan dengan 14 (empat belas) kategori lainnya. Sementara peranan 14 kategori lainnya tersebut adalah di bawah 5 persen (Badan Pusat Statistik Kabupaten Kepulauan Meranti 2016).

Pertumbuhan ekonomi merupakan salah satu acuan dalam melihat tingkat perekonomian dalam suatu wilayah. Semakin tinggi pertumbuhan ekonomi ini menggambarkan semakin tingginya tingkat investasi dalam suatu wilayah.Pertumbuhan ekonomi Kabupaten Kep Meranti berfluktuasi setiap tahunnya. Untuk mengetahui pertumbuhan ekonomi tiap tahunnya dapat dilihat pada Gambar 1.

\section{Analisis Location Quationt (LQ)}

Hasil perhitungan analisis Location Quationt (LQ) Kabupaten Kep Meranti dalam kurun waktu tahun 2011-2015 dapat teridentifikasi yang mana sektor basis dan non basis perekonomian tanpa migas pada Tabel 2.

Berdasarkan tabel diatas terdapat empat sektor yang memiliki trend nilai besar dari satu yang termasuk kategori sektor basis yakni Sektor Pertanian, Kehutanan, dan Perikanan, Sektor Industri pengolahan, Sektor Transportasi dan Pergudangan, dan Sektor Administrasi Pemerintahan; Pertahanan, dan Jaminan Sosial Wajib. Sektor ini menjadi leading sektor perekonomian sekaligus menjadi sektor yang dominan dalam penyerapan tenaga kerja di Kabupaten Kepulauan Meranti.

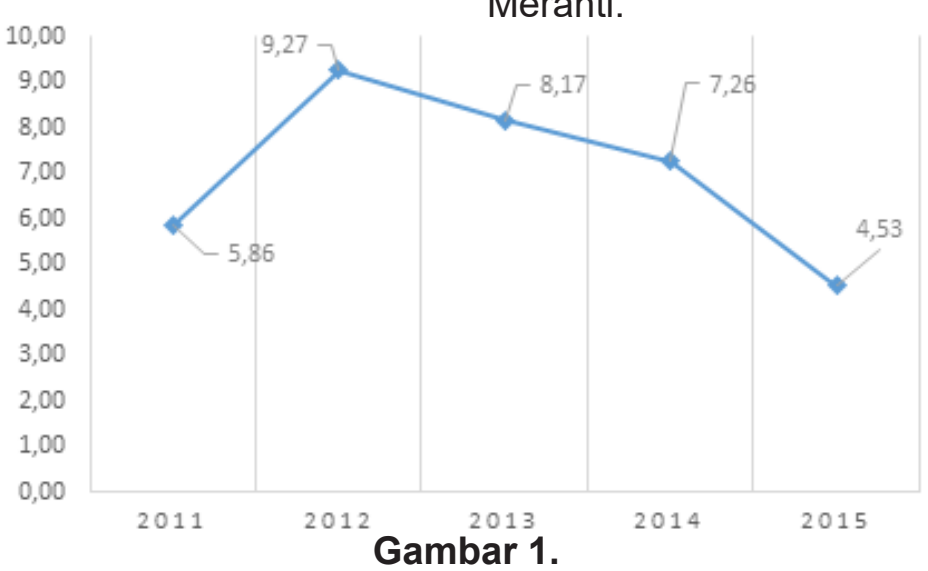

Laju Pertumbuhan Ekonomi (Non Migas), Tahun 2011-2015

Berdasarkan data PDRB non Migas yang dilihat pada gambar diatas, menunjukkan bahwa pertumbuhan ekonomi real tanpa migas turun setiap tahunnya, hingga pada tahun 2015 sebesar 4,53 persen dari 9,27 persen di tahun 2012. Penurunan yang terjadi ini juga dikarenakan lesunya kegiatan perekonomian lokal yang mana belum fokusnya daerah dalam menentukan sektor unggulan sehingga belum terjadinya spesialisasi sektor dan tujuan ekspor daerah. Hal ini akan berdampak pada menurunnya minat investor untuk berinvestasi.
Hasil penelitian ini sejalan dengan penelitian Kornita (2008); Rudi et al. (2014); Rosyetti (2011) yang menyatakan sektor unggulan di sebagain wilayah Provinsi Riau yaitu Sektor Pertanian, Kehutanan, dan Perikanan, Sektor Industri pengolahan. Hasil penelitian Syarifah (2012) menyatakan sektor unggulan yang ada di Provinsi Jawa Tengah yaitu sektor Pertanian. Sedangkan hasil penelitian Putra \& Kartika (2013)tidak sejalan dengan hasil peneltitian ini dikarenakan sektor unggulan yang terdapat di Kab. Badung adalah Sektor Listrik, gas, dan air bersih, 
Sektor Bangunan, Sektor perdagangan, tor ini juga di dukung dari sub sektor perhotel, dan restoran, dan Sektor Pengang- tambangan dan penggalian lainnya yang kutan dan Komunikasi.

Tabel 2

Nilai LQ Tanpa Migas Kabupaten Kep Meranti, Tahun 2011-2015

\begin{tabular}{|c|c|c|c|c|c|c|c|}
\hline \multirow{2}{*}{ NO } & \multirow{2}{*}{ Lapangan Usaha } & \multicolumn{6}{|c|}{ Nilai LQ } \\
\hline & & 2011 & 2012 & 2013 & 2014 & 2015 & Rataan \\
\hline 1 & Pertanian, Kehutanan, dan Perikanan & 1.51 & 1.51 & 1.47 & 1.48 & 1.45 & 1.48 \\
\hline 2 & Pertambangan \& Penggalian & 0.01 & 0.01 & 0.07 & 0.07 & 0.06 & 0.04 \\
\hline 3 & Industri Pengolahan & 1.03 & 1.03 & 1.06 & 1.10 & 1.14 & 1.07 \\
\hline 4 & Pengadaan Listrik dan Gas & 0.84 & 0.95 & 0.99 & 0.58 & 0.59 & 0.79 \\
\hline 5 & $\begin{array}{l}\text { Pengadaan Air, Pengelolaan Sampah, } \\
\text { Limbah, dan Daur Ulang }\end{array}$ & 0.38 & 0.39 & 0.41 & 0.43 & 0.42 & 0.41 \\
\hline 6 & Konstruksi & 0.41 & 0.38 & 0.40 & 0.44 & 0.42 & 0.41 \\
\hline 7 & $\begin{array}{l}\text { Perdagangan Besar dan Eceran, } \\
\text { Reparasi Mobil dan Sepeda Motor }\end{array}$ & 0.78 & 0.87 & 0.83 & 0.73 & 0.76 & 0.80 \\
\hline 8 & Transportasi dan Pergudangan & 2.63 & 2.79 & 2.67 & 2.74 & 2.62 & 2.69 \\
\hline 9 & $\begin{array}{l}\text { Penyediaan Akomodasi dan Makan } \\
\text { Minum }\end{array}$ & 0.44 & 0.41 & 0.38 & 0.34 & 0.37 & 0.39 \\
\hline 10 & Informasi dan Komunikasi & 1.01 & 0.92 & 0.91 & 0.92 & 0.91 & 0.93 \\
\hline 11 & Jasa Keuangan dan Asuransi & 0.35 & 0.34 & 0.28 & 0.29 & 0.29 & 0.31 \\
\hline 12 & Real Estate & 0.47 & 0.47 & 0.46 & 0.48 & 0.48 & 0.47 \\
\hline 13 & Jasa Perusahaan & 0.56 & 0.56 & 0.56 & 0.56 & 0.58 & 0.56 \\
\hline 14 & $\begin{array}{l}\text { Administrasi Pemerintahan; } \\
\text { Pertahanan, dan Jaminan Sosial } \\
\text { Wajib }\end{array}$ & 1.22 & 1.14 & 1.17 & 1.25 & 1.28 & 1.21 \\
\hline 15 & Jasa Pendidikan & 0.42 & 0.41 & 0.39 & 0.37 & 0.34 & 0.38 \\
\hline 16 & Jasa Kesehatan dan Kegiatan Sosial & 0.35 & 0.33 & 0.33 & 0.33 & 0.32 & 0.33 \\
\hline 17 & Jasa Lainnya & 0.65 & 0.65 & 0.64 & 0.63 & 0.55 & 0.62 \\
\hline
\end{tabular}

Sumber: Data Olahan, 2017

\section{Shift Share Analysis}

Didalam analisis ini pertumbuhan PDRB akan didekomposisikan menjadi tiga komponen yang terdiri dari Regional Share, Proportional Shift dan Differential Shift. Hasil perhitungan Shift Share Analysis Kabupaten Kep Meranti dalam kurun waktu tahun 2011-2015 dapat dilihat di Tabel 3 .

Berdasarkan Tabel 3, diketahui sektor yang memiliki keuntungan kompetitif atau daya saing yang ditunjukkan dengan differential shift bernilai positif hanya satu sektor yaitu sektor pertambangan \& penggalian dikarenakan sektor ini mulai berkembang di tahun 2013 dengan mulai beroperasinya pertambangan timah yang dengan sendirinya meningkatkan nilai tambah pada subsektor pertambangan bijih logam, selain itu perkembangan sek- mengalami trend meningkat tiap tahunnya. Hasil ini sejalan dengan penelitian Rosyetti (2011) yang menyatakan sektor pertambangan memiliki nilai differential shift positif di Kabupaten Kuantan Singingi.

Perhitungan Proportional shift bertujuan untuk mengetahui apakah perekonomian daerah terkonsentrasi pada industri (sektor) yang tumbuh lebih cepat ketimbang perekonomian yang menjadi acuan. Berdasarkan tabel diatas, terdapat 12 sektor yang memiliki nilai proportional shift positif yaitu sektor Pengadaan Listrik dan Gas; Konstruksi; Perdagangan Besar dan Eceran, Reparasi Mobil dan Sepeda Motor; Transportasi dan Pergudangan; Penyediaan Akomodasi dan Makan Minum; Informasi dan Komunikasi; Jasa Keuangan dan Asuransi; Real Estate; dan Jasa Perusahaan. Masing-masing sektor 
Tabel 3.

Hasil Perhitungan Shift Share Analysis Kabupaten Kep Meranti Tahun 2011-2015

\begin{tabular}{crrrrr}
\hline $\begin{array}{c}\text { Lap } \\
\text { Usaha }\end{array}$ & $\begin{array}{c}\text { Regional } \\
\text { Share }\end{array}$ & $\begin{array}{c}\text { Proportionality } \\
\text { Shift }\end{array}$ & Differential Shift & Total $\Delta y i$ & $\begin{array}{r}\text { Pergerakan } \\
\text { Bersih (P+S) }\end{array}$ \\
\hline 1 & $1,821,474.36$ & $-239,034.44$ & -847.319 .67 & $735,120.25$ & $-1,086.354 .11$ \\
2 & $1,821.83$ & -35.06 & $45,272.48$ & $47,059.25$ & $45,237.42$ \\
3 & $1,222,014.83$ & $-174,089.07$ & $-142,619.26$ & $905,306.50$ & $-316,708.33$ \\
4 & $1,830.38$ & 189.71 & $-2,103.11$ & -83.02 & $-1,913.40$ \\
5 & 270.26 & -157.63 & -23.57 & 89.05 & -181.21 \\
6 & $151,148.17$ & $43,284.18$ & $-50,293.18$ & $144,139.17$ & $-7,009.00$ \\
7 & $311,331.94$ & $134,017.87$ & $-162,198.83$ & $283,150.98$ & $-28,180.96$ \\
8 & $91,499.30$ & $45,865.52$ & $-42,269.05$ & $95,095.77$ & $3,596.47$ \\
9 & $8,972.04$ & $7,880.50$ & $-9,703.72$ & $7,148.82$ & $-1,823.22$ \\
10 & $31,174.66$ & $3,537.98$ & $-20,674.58$ & $14,038.06$ & $-17,136.60$ \\
11 & $14,291.19$ & $3,420.40$ & $-11,822.49$ & $5,889.09$ & $-8,402.10$ \\
12 & $18,646.99$ & $3,537.40$ & $-6,382.60$ & $15,801.79$ & $-2,845.20$ \\
13 & 113.21 & 86.01 & -44.30 & 154.92 & 41.71 \\
14 & $106,305.03$ & $-25,986.40$ & $-26,540.41$ & $53,778.22$ & $-52,526.81$ \\
15 & $10,045.93$ & $1,923.82$ & $-8,978.43$ & $2,991.32$ & $-7,054.61$ \\
16 & $2,622.69$ & $1,908.57$ & $-2,029.22$ & $2,502.05$ & -120.64 \\
17 & $12,006.65$ & $7,183.58$ & $-11,106.72$ & $8,083.51$ & $-3,923.14$ \\
\hline Jumlah & $3,805,569.45$ & $-186,467.07$ & $-1,298,836.65$ & $2,320,265.73$ & \\
\hline Persen & $164.01 \%$ & $-8.04 \%$ & $-55.98 \%$ & $100 \%$ & \\
\hline Sumber. Data Olahan Penelitian, 2017, Keterangan Lapangan Usaha merujuk pada Tabel 2
\end{tabular}

ini mengalami peningkatan tiap tahunnya mengikuti perekonomian daerah eksternal dan sebagain sektor telah menjadi leading sektor perekonomian seperti sektor transportasi dan pergudangan. Hasil ini sejalan dengan penelitian Rudi et al. (2014) (Rudi et al. 2014) yang menyatakan sektor Perdagangan, Hotel, dan Restoran di Kabupaten Kepulauan Meranti memiliki nilai proportional shift positif. Peningkatan output pada sektor Perdagangan, Hotel, dan Restoran lebih banyak didorong oleh kebijakan pemerintah pusat dan provinsi serta industri yang bergerak pada sektor tersebut.

Berdasarkan nilai pergerakan bersih hanya terdapat 3 sektor yang memiliki nilai positif yang termasuk ke dalam kelompok progresif (maju) yaitu Sektor Pertambangan \& Penggalian; Sektor Transportasi dan Pergudangan; dan Sektor Jasa Perusahaan.

\section{Indeks Spesialisasi}

Kajian keterkaitan antar-wilayah ini sangat dibutuhkan untuk melihat peran daerah dalam perekonomian bagi daerah lainnya. Berdasarkan hasil perhitungan indeks spesialisasi, maka dapat terlihat pola spesialisasi perekonomian antar-wilayah di Provinsi Riau dengan menjadikan Kabupaten Kep Meranti sebagai pusat interaksi.

Berdasarkan Gambar 2 perkembangan keterkaitan perekonomian Kabupaten Kep Meranti dengan wilayah Kabupaten/Kota di Provinsi Riau dari tahun 2011 sampai tahun 2015 masih didominasi oleh pengaruh Kota Pekanbaru dan Kabupaten Bengkalis yang mana angka keterkaitan antar wilayah bernilai diatas satu yakni sebesar 1,1968 dan 1,0485. Hal ini disebabkan Kota Pekanbaru merupakan Ibu Kota Provinsi Riau yang mana setiap kebijakan yang di ambil dalam pembangunan daerah Kota Pekanbaru lebih menjadi prioritas provinsi serta Kota Pekanbaru merupakan salah satu koridor MP3El. Sementara itu, dominasi Kabupaten Bengkalis dikarenakan Kabupaten Kep Meranti merupakan wilayah pemekarannya sehingga interaksi kedua daerah ini baik perekonomian dan sosial masih sangat erat yang menjadikan dae- 
rah ini belum bisa move on.

Selanjutnya untuk daerah yang memiliki nilai Indeks dibawah satu mengindikasikan bahwa daerah tersebut tidak memiliki aktivitas yang terdiversifikasi atau cenderung memiliki aktivitas yang tidak terspesialisasi (specialization). Hal ini salah satunya disebabkan letak geografis yang berjauhan dan dipisahkan oleh laut sehingga membuat biaya ke daerah ini menjadi tinggi, hal lainnya terkait infrastruktur penyeberangan belum banyak yang secara otomatis akan menjadikan mobilitas barang dan manusia menjadi tidak lancar. Hal yang seperti ini mesti diperhatikan oleh Pemda untuk kemajuan di jangka panjang. maka didapat empat sektor unggulan yang terdiri dari dua sektor unggulan utama dan dua sektor unggulan pendukung dapat dilihat pada Tabel 4.

Berdasarkan tabel diatas yang menjadi sektor unggulan pertama yakni sektor Transportasi dan Pergudangan, adapun dasar pemilihan dari nilai LQ termasuk kategori basis, lalu dari nilai proportional shift nya juga positif yang mengindikasikan ekonomi daerah terkonsentrasi pada sektor yang tumbuh lebih cepat ketimbang perekonomian yang menjadi acuan. Adapun nilai differential shift nya yang masih negatif lebih diakibatkan hampir keseluruhan sektor memiliki nilai negatif namun

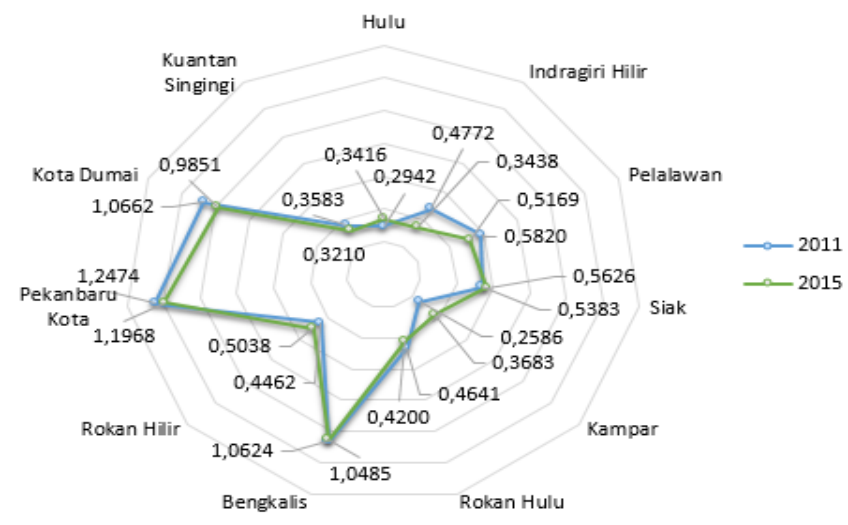

Gambar 2.

Pola Keterkaitan Antar-Wilayah Kabupaten/Kota Provinsi Riau dengan Kabupaten Kep Meranti, Tahun 2011-2015

Berdasarkan hasil perhitungan LQ diatas apabila disingkronkan dengan hasil indeks spesialisasi, maka Kabupaten Kep Meranti termasuk memiliki peranan penting serta pendukung kegiatan perekonomian daerah yang berada di pesisir Provinsi Riau.

\section{Pembahasan Sektor Potensial}

Untuk mengetahui sektor potensial di Kabupaten Kep Meranti dilakukan analisis dengan cara mengambil kesimpulan dari gabungan hasil analisis sebelumnya yakni analisis Location Quationt, Shift Share Analysis, dan Indeks Spesialisasi. Berdasarkan gabungan tiga analisis ini demikian pada bagian nilai pergerakan bersih bernilai positif yang termasuk ke dalam kelompok progresif (maju). Selanjutnya dari nilai Indeks Spesialisasi mengindikasikan nilai positif tetapi belum melebihi nilai satu. Sektor ini apabila terus dikembangkan akan mendukung pergerakan sektor perekonomian lainnya dikarenakan letak geografis yang berbentuk Kep sehingga membutuhkan sarana dan prasarana transportasi dan pergudangan demi kelancaran mobilitas barang dan jasa.

Selanjutnya untuk sektor unggulan yang kedua yaitu pertanian, kehutanan, dan perikanan. Pemilihan ini berdasarkan nilai LQ dan nilai indeks spesialisasi besar 
dari satu, sementara itu nilai dari perhitungan dekomposisi shift share tidak ada yang positif. Berdasarkan keadaan real, penduduk Kabupaten Kep Meranti dominan bekerja di sektor pertanian sehingga upaya-upaya yang dilakukan dalam rangka peningkatan produksi akan bermanfaat pada kesejahteraan masyarakat secara keseluruhan. Upaya-upaya tersebut meliputi intensifikasi, ekstensifikasi, diversifikasi (spesialisasi), dan rehabilitasi. paten Kep Meranti yang mana investasi dapat mendorong pertumbuhan ekonomi daerah, maka dengan penentuan sektor potensial tersebut diharapkan pemerintah daerah memprioritaskan promosi dan realisasi investasi pada sektor potensial tersebut, sebelumnya pemerintah harus mempersiapkan infrastruktur dasar pendukung sektor potensial ini guna menambah daya tarik investor dalam dan luar negeri.

Tabel 4.

Ringkasan Analisis Sektor Potensial Berdasarkan LQ, Shift Share Analysis, dan Indeks Spesialisasi Kabupaten Kep Meranti

\begin{tabular}{|c|c|c|c|c|c|c|}
\hline NO & Lapangan Usaha & $\begin{array}{l}\text { Proportionality } \\
\text { Shift }\end{array}$ & $\begin{array}{l}\text { Differential } \\
\text { Shift }\end{array}$ & $\begin{array}{l}\text { Pergerakan } \\
\text { Bersih }(\mathrm{P}+\mathrm{S})\end{array}$ & LQ & IS \\
\hline 1 & $\begin{array}{l}\text { Transportasi dan } \\
\text { Pergudangan }\end{array}$ & $45,865.52$ & $-42,269.05$ & $3,596.47$ & 2.62 & 0.172 \\
\hline 2 & $\begin{array}{l}\text { Pertanian, } \\
\text { Kehutanan, dan } \\
\text { Perikanan }\end{array}$ & $-239,034.44$ & $-847,319.67$ & $-1,086,354.11$ & 1.45 & 1.204 \\
\hline 3 & $\begin{array}{l}\text { Industri } \\
\text { Pengolahan }\end{array}$ & $-174,089.07$ & $-142,619.26$ & $905,306.50$ & 1.14 & -0.259 \\
\hline
\end{tabular}

Sektor unggulan ketiga yaitu sektor industri pengolahan. Pemilihan sektor ini berdasarkan nilai $L Q$ yang besar dari satu dan nilai pergerakan bersih yang positif sehingga sektor ini masuk kategori sektor maju atau progresif. Kontribusi sektor industri pengolahan terhadap PRDB merupakan ke-dua terbesar. Sektor ini sendiri pada dasarnya membutuhkan input dari sektor pertanian dan kelancaran mobilitas barang serta pergudangan. Sehingga apabila sektor ini disinergikan dengan dua sektor unggulan sebelumnya yakni sektor pertanian dan sektor transportasi dan pergudangan maka sektor ini perlahan akan meningkat dan struktur perekonomian akan bergeser ke industri.

Hasil kajian ini bila disingkronkan dengan hasil penelitian Darwin \& Hidayat (2016) tentang investasi asing di Kabu-

\section{Penutup}

Berdasarkan hasil dan pembahasan dapat disimpulkan bahwa sektor potensial yaitu Sektor Transportasi dan Pergudangan; Sektor Pertanian, Kehutanan, dan Perikanan; dan Sektor Industri pengolahan. Saran yang dapat diberikan dalam menentukan arah kebijakan pembangunan wilayah Kabupaten Kepulauan Meranti sebagai berikut: 1) Pemerintah Kabupaten Kep Meranti diharapkan merumuskan strategi pengembangan daerah dengan mengutamakan kegiatan unggulan dari sektor Transportasi dan Pergudangan; Sektor Pertanian, Kehutanan, dan Perikanan; dan Sektor Industri pengolahan. Namun dalam upaya meningkatkan pertumbuhan ekonomi melalui sektor basis hendaknya pemerintah tidak mengabaikan sektor non basis karena peran sektor 
non basis diharapkan dapat menjadi sektor basis yang baru sehingga semua sektor ekonomi dapat mendukung tercapainya peningkatan pertumbuhan ekonomi. 2) Pemerintah daerah diharapkan mempersiapkan infrastruktur dasar pendukung sektor potensial guna menambah daya tarik investor dalam dan luar negeri.

\section{Daftar Pustaka}

Badan Pusat Statistik Kabupaten Kepulauan Meranti, 2016. Statistik Daerah Kabupaten Kepulauan Meranti 2016, Selat Panjang: BPS Kabupaten Kep. Meranti.

Darwin, R. dan Hidayat, M., 2016. Analisis Investasi Terhadap Pembangunan Ekonomi Wilayah Kabupaten Meranti (Pendekatan Forecasting Analysis). In Celscitech - UMRI. Pekanbaru: LP2MUMRI, p. Eco 14-20.

Deddy, M. danlrwansyah, S., 2013. Analisis Pergeseran Struktur Ekonomi dan Identifikasi Sektor Potensial Wilayah Pengembangan (Studi Kasus di Kabupaten Bekasi, Provinsi Jawa Barat). Jurnal Social Economic of Agriculture, 2(1), pp.7-28.

Hidayat, M., 2014. Inequality across districts and cities in the Riau. Economic Journal of Emerging Markets, 6(2), pp.106-118.

Kim, S., 1995. Expansion of Markets and the Geographic Distribution of Economic Activities: The Trends in U. S. Regional Manufacturing Structure, 1860-1987. The Quarterly Journal of Economics, 110(4), pp.881-908. Available at: http://qje.oxfordjournals.org/ cgi/doi/10.2307/2946643 [Accessed January 19, 2017].

Kornita, S.E., 2008. Analisis Sektor Ekonomi Unggulan di Provinsi Riau. In Warta ISEI. Pekanbaru: ISEI.

Putra, G.B.N.P. danKartika, I.N., 2013. Analisis Sektor-Sektor Potensial Dalam Menentukan Prioritas Pembangunan di
Kabupaten Badung Tahun 2001-2011. E-Jurnal Ekonomi Pembangunan Universitas Udayana, 2(9), pp.401-405.

Rosyetti, 2011. Analisis Sektor Potensial Kabupaten Kuantan Singingi. Jurnal Ekonomi, 19(1).

Rudi, A.R., Zainal, H. dan Yani, K.S., 2014. Keterkaitan Sektor-Sektor Ekonomi Potensial di Provinsi Riau. MIMBAR, 30(1), pp.62-71.

Sjafrizal, 2012. Ekonomi Wilayah dan Perkotaan, Jakarta: PT. Raja Grafindo Persada.

Sjafrizal, 2014. Perencanaan Pembangunan Daerah Dalam Era Otonomi, Jakarta: Rajawali Pers.

Syarifah, N., 2012. Analisis Tingkat Spesialisasi Regional Dalam Pembangunan Ekonomi Jawa Tengah Tahun 20022006. Universitas Muhammadiyah Malang. Available at: http://eprints. umm.ac.id/id/eprint/7631. 